\title{
Kinetic Modeling of Plasma Leucine Levels during Continuous Venovenous Extracorporeal Removal Therapy in Neonates with Maple Syrup Urine Disease
}

\author{
PHILIPPE JOUVET, PHILIPPE HUBERT, JEAN MARIE SAUDUBRAY, DANIEL RABIER, AND \\ NGUYEN K. MAN \\ Pediatric Intensive Care Unit [P.J., P.H.], Pediatric Metabolic Unit [J.M.S.], Biochemistry Department \\ [D.R.], Nephrology Department and INSERM U 507 [N.K.M.], Hôpital Necker Enfants Malades, 75015 \\ Paris, France
}

\begin{abstract}
ABSTR
A kinetic modeling of leucine plasma concentration changes
is proposed to describe the plasma leucine reduction rate during
continuous extracorporeal removal therapy $(\mathrm{CECRT})$ in neonates
with maple syrup urine disease. Data were obtained from seven
neonates using a bicompartmental model for the best fitted curve
of plasma leucine decrease during CECRT. During the first $3 \mathrm{~h}$,
leucine plasma levels decreased according to an exponential
curve: $[\mathrm{Leu}]_{\mathrm{t}}=[\mathrm{Leu}]_{\mathrm{i}} \times 0.95 \times 10^{-0.09 t}$ where $[\text { Leu }]_{\mathrm{t}}$ is the
leucine plasma level $(\mu \mathrm{mmol} / \mathrm{L})$ at time $\mathrm{t}$ (h) during CECRT and
$[\text { Leu }]_{\mathrm{I}}$ is the initial plasma level. From $\mathrm{h} 4$ to the end of CECRT,
a second exponential curve was observed: $[\text { Leu }]_{\mathrm{t}}=[\mathrm{Leu}]_{\mathrm{i}} \times$
$0.74 \times 10^{-0.05 t}$. Plasma leucine levels obtained from three other
neonates were similar to those predicted by the model. The
apparent distribution volumes for leucine that correspond to the
two exponential equations obtained were calculated from the
leucine mass removal collected in the spent dialysate and ultra-
\end{abstract}
filtrate. The distribution volume was $34 \pm 3 \%$ of body weight during the first $3 \mathrm{~h}$ of CECRT and $72 \pm 7 \%$ from $\mathrm{h} 4$ to the end of CECRT. These figures are similar to known values for the extracellular water compartment and for total body water in the newborn. The findings suggest that leucine handling during CECRT is similar to that of nonprotein-bound small-molecularweight solutes such as urea. (Pediatr Res 58: 278-282, 2005)

\[ \text { Abbreviations } \]
BCAA, branched chain amino acids
CECRT, continuous extracorporeal removal therapy
MSUD, maple syrup urine disease
NICU, neonatal intensive care unit
$\mathbf{N}_{\text {leu }}$, leucine mass
Vd, distribution volume

MSUD is an inherited metabolic disease due to a deficiency in branched chain ketoacid dehydrogenase that leads to the accumulation of BCAA (leucine, isoleucine, and valine) and their keto-acid derivatives (1). Because of this impaired enzyme activity, leucine accumulates in cells and body fluids when the load exceeds leucine metabolism capacity and/or when a increased protein catabolism occurs. Given that renal clearance of BCAA and its derivatives is poor and due to the fact that their acute elevation causes neurologic deterioration, CECRT is indicated in severe cases and/or when nutritional support free of BCAA is not possible (2).

Received January 20, 2004; accepted November 10, 2204.

Correspondence: Philippe Jouvet, M.D., Ph.D., Soins Intensifs Pédiatriques, Hôpital Sainte Justine, 3175 chemin Côte Sainte Catherine, Montréal (Québec) H3T 1C5, Canada; E-mail: philippe.jouvet@umontreal.ca

This study was supported by "Assistance Publique-Hôpitaux de Paris" (grant number CRC 950180) and the Hospal International.

DOI: 10.1203/01.PDR.0000169982.06717.67
Because assessment of leucine plasma levels by amino acid chromatography is not easily available and is time consuming, the aim of this study was to design a kinetic model that predicts leucine plasma level changes over time during the acute phase of the illness in neonates on CECRT.

\section{METHODS}

Patients. Between January 1991 and April 2000, seven neonates with MSUD presented with a severe acute deterioration of their status. After a 6-h period of conservative management that included correction of dehydration and increased caloric intake, all seven patients presented two of the three following criteria that are associated with a high risk of severe brain damage: comatose state, gastrointestinal intolerance, and leucine plasma levels $\geq 1700$ $\mu \mathrm{M}$. The patients were referred to pediatric and neonatal intensive care for alternative therapies, in particular CECRT (3). Blood and spent dialysate samples were collected to monitor treatment efficiency. We retrospectively used these biologic analyses to elaborate the parameters involved in leucine kinetic modeling during CECRT (Table 1). Subsequently, between May 2000 and December 2001, three other neonates were treated with the same therapeutic strategy and were retrospectively studied to validate the leucine kinetic modeling proposed (Table 2). Approval to undertake this study was obtained 
Table 1. Kinetic modeling of leucine plasma concentration changes derived from data obtained from seven neonates with acute phase maple syrup urine disease treated with CECRT

\begin{tabular}{|c|c|c|c|c|c|c|c|c|c|c|c|c|}
\hline \multirow[b]{2}{*}{ Patient } & \multirow[b]{2}{*}{$\begin{array}{l}\mathrm{BW} \\
(\mathrm{kg})\end{array}$} & \multirow[b]{2}{*}{$\begin{array}{l}\text { Age at treatment } \\
\text { (days) }\end{array}$} & \multicolumn{4}{|c|}{ CECRT } & \multicolumn{2}{|c|}{$\begin{array}{c}\text { Leucine } \\
\text { plasma level }\end{array}$} & \multicolumn{4}{|c|}{ Leucine } \\
\hline & & & $\begin{array}{c}\mathrm{T} \\
(\mathrm{hr})\end{array}$ & QS & $\begin{array}{c}\text { QD } \\
(\mathrm{ml} / \mathrm{min})\end{array}$ & $\mathrm{QF}$ & $\begin{array}{l}\text { initial } \\
(\mu \mathrm{M})\end{array}$ & $\begin{array}{r}\text { final } \\
(\mu \mathrm{M})\end{array}$ & $\begin{array}{l}\text { mass removal } \\
(\mathrm{mmol} / \mathrm{session})\end{array}$ & $\begin{array}{c}\mathrm{Cl} \\
(\mathrm{ml} / \mathrm{min})\end{array}$ & $\begin{array}{c}\mathrm{Vd} 1 \\
(\% \mathrm{BWt})\end{array}$ & $\begin{array}{c}\mathrm{Vd} 2 \\
(\% \mathrm{BWt})\end{array}$ \\
\hline 1 & 3.7 & 12 & 12 & 20 & 0 & 2.0 & 2186 & 1131 & 2.0 & 1.7 & 37 & 42 \\
\hline 2 & 2.9 & 11 & 11 & 20 & 16 & 1.0 & 3818 & 1275 & 6.6 & 4.3 & 45 & 95 \\
\hline 3 & 2.0 & 22 & 12 & 20 & 25 & 0.0 & 2536 & 488 & 3.5 & 3.9 & 42 & 89 \\
\hline 4 & 3.2 & 16 & 13 & 30 & 0 & 7.4 & 3117 & 679 & 5.1 & 3.5 & 25 & 75 \\
\hline 5 & 3.1 & 12 & 12 & 40 & 0 & 8.7 & 2226 & 305 & 4.0 & 4.1 & 29 & 68 \\
\hline 6 & 3.2 & 13 & 11 & 40 & 0 & 9.5 & 3189 & 196 & 6.2 & 4.8 & 24 & 60 \\
\hline 7 & 2.4 & 12 & 8 & 30 & 27 & 0.0 & 1629 & 496 & 2.3 & 2.8 & 36 & 76 \\
\hline Mean \pm SEM & & & & & & & & & & $3.6 \pm 0.4$ & $34 \pm 3$ & $72 \pm 7$ \\
\hline
\end{tabular}

Continuous veno-venous extracorporeal removal therapy (CECRT) characteristics, leucine plasma levels, leucine mass removal, leucine integrated clearance and sequential distribution volumes (Vd) with CECRT. Vd was calculated according to the following formula and expressed as a percentage of body weight (BW) $: \mathrm{Vd}=\left(\mathrm{N} /\left(\mathrm{C}_{\mathrm{t} 1}-\mathrm{C}_{\mathrm{t} 2}\right)\right) \times 100 / \mathrm{BW}$ where $\mathrm{C}_{\mathrm{t} 1}$ and $\mathrm{C}_{\mathrm{t} 2}$ is the leucine plasma level at the start and the end of spent dialysate collection and $N$ is leucine mass removal during the defined period. Vd1 corresponds to extracellular volume (34\% body weight) and $\mathrm{Vd} 2$ to total body water (72\% body weight).

T, CECRT duration; QS, blood flow; QD, dialysate flow; QF, filtration and fluid replacement flow (net ultrafiltration was nil); Cl, integrated clearance; Vd1, leucine distribution volume during the first three hours of CECRT; Vd2, leucine distribution volume during the last three hours of CECRT; SEM, standard error of the mean.

Table 2. Leucine kinetic modeling validation performed with retrospectively acquired data from three neonates with acute phase maple syrup urine disease treated with CECRT

\begin{tabular}{|c|c|c|c|c|c|c|c|c|c|}
\hline \multirow[b]{2}{*}{ Patient } & \multirow[b]{2}{*}{$\mathrm{BW}(\mathrm{kg})$} & \multirow[b]{2}{*}{$\begin{array}{c}\text { Age at treatment } \\
\text { (days) }\end{array}$} & \multicolumn{4}{|c|}{ CECRT } & \multicolumn{3}{|c|}{ Leucine plasma level } \\
\hline & & & $\mathrm{T}$ (hrs) & QS & $\mathrm{QD}(\mathrm{ml} / \mathrm{min})$ & QF & $\begin{array}{l}\text { initial } \\
(\mu \mathrm{M})\end{array}$ & $\begin{array}{c}\text { at 3h of CECRT } \\
(\mu \mathrm{M})\end{array}$ & $\begin{array}{r}\text { final } \\
(\mu \mathrm{M})\end{array}$ \\
\hline 9 & 2.7 & 9 & 3 & 25 & 25 & 0.0 & 3489 & 1388 & - \\
\hline 9 & 2.7 & 10 & 7 & 25 & 25 & 0.0 & 1680 & 844 & 513 \\
\hline 10 & 3.1 & 9 & 10 & 25 & 25 & 0.0 & 2782 & 1464 & 631 \\
\hline
\end{tabular}

Continuous veno-venous extracorporeal removal therapy (CECRT) characteristics and leucine plasma levels at several time points during CECRT. Patient nine underwent a second CECRT session due to filter clotting which occurred at time three hours after initiation of the first session.

T, CECRT duration; QS, blood flow; QD, dialysate flow; QF, filtration and fluid replacement flow (net ultrafiltration was nil).

* leucine level at $5 \mathrm{~h} 30$ of CECRT.

from the Necker Institutional Review board and informed consent was obtained from the parents of all patients included.

Patient management. Newborns were placed in a radiant warmer and mechanically ventilated and sedated. Continuous monitoring of heart rate, temperature, and transcutaneous oxygen saturation was performed. A hemodialysis catheter (6.5-French dual lumen catheter, Hospal Medical Corporation, East Brunswick, NJ) was inserted into the femoral or internal jugular vein. Blood samples were drawn every 3-6 h to obtain blood gases, hematocrit, and activated clotting time as well as total protein, sodium, potassium, calcium, phosphate, urea, and creatinine levels. Blood amino acid chromatography was performed before CECRT, at least twice daily during its course and just before its cessation.

The therapeutic strategy used is described in a previous publication (3) and included resumption of nutritional support $2 \mathrm{~h}$ after CECRT initiation. CECRT was performed using a FH 22 Gambro $\left(0.2 \mathrm{~m}^{2}\right.$ polyamide membrane) or Miniflow 10 Hospal ( $420 \mathrm{~cm}^{2}$ AN 69 membrane) hemofilter connected to the central venous catheter via a dedicated neonatal blood circuit (priming blood volume $=35 \mathrm{~mL}$ ). Blood flow was continuously monitored (AK-10, Gambro, Colombes, France; BSM 22 PM or Prisma, Hospal, Lyon, France; BM 11, Baxter, Versailles, France). A $4 \%$ albumin solution was used to prime the extracorporeal blood circuit and a sodium heparin solution was infused into the arterial line at a rate of $10 \mathrm{IU} / \mathrm{kg} / \mathrm{h}$ to achieve an activated clotting time 1.5 times that of control. The same sterile nonpyrogenic fluid was used as either dialysate or replacement fluid and was prepared by mixing $5 \mathrm{~L}$ of HF 140 (Fresenius Medical Care, Sèvres, France) with $190 \mathrm{~mL}$ of $8.4 \%$ sodium bicarbonate and $10 \mathrm{mmol}$ of $7.46 \% \mathrm{KCl}$ to achieve the following composition (in mmol/L): $\mathrm{Na}^{+} 140, \mathrm{~K}^{+} 3, \mathrm{Ca}^{++} 1.75, \mathrm{Mg}^{++} 0.5, \mathrm{HCO}_{3}^{-} 35, \mathrm{Cl}^{-} 107$ and $\mathrm{CH}_{3} \mathrm{COO}^{-}$3. Replacement fluid was administered in a predilution mode. For the purpose of fluid balance in the study, the volumes of total fresh dialysate, spent dialysate, ultrafiltrate, and replacement fluid were recorded. Flow rate was determined according to hemofilter type, pump ability, and body weight. Twenty milliliter samples drawn from the spent dialysate and the ultrafiltrate bag were frozen for BCAA analysis.

Calculation. Leucine mass removal, $\mathrm{N}_{\text {Leu }}$, is the product of leucine concentration in the ultrafiltrate and spent dialysate and their volume. The integrated clearance (CI) is calculated according to the formula CI $=\mathrm{N}_{\text {leu }} /(\mathrm{Pm}$ $\times \mathrm{td}$ ), where $\mathrm{Pm}$ is the mean leucine plasma concentration and td is the session duration in minutes.

The leucine $\mathrm{Vd}$ is the ratio of the leucine mass removal to leucine plasma level decrease during a defined period: $\mathrm{Vd}=\mathrm{N}_{\mathrm{Leu}} /\left(\mathrm{C}_{\mathrm{t} 1}-\mathrm{C}_{\mathrm{t} 2}\right)$ where $\mathrm{C}_{\mathrm{t} 1}$ and $\mathrm{C}_{\mathrm{t} 2}$ are the leucine plasma levels at the start and the end of spent dialysate collection. Distribution volumes were expressed as a percentage of body weight $[(\mathrm{Vd} \times 100) /$ body weight $]$.

Leucine kinetic modeling. Based on data obtained from the first seven neonates, kinetic modeling was attempted to describe the time course of plasma leucine levels during CECRT. Least square statistical analysis was used to attain the best fitted curve, which was defined as a linear or exponential curve with a coefficient of determination $\left(r^{2}\right)>0.95$. Curve fitting was carried out with CA-Cricket Graph III software for the Macintosh (Computer Associates International, Islandia, NY). Given that all seven patients were newborns with a classic form of MSUD and similar weight and age, an integrated leucine clearance within the same range, and no other disease, we included the mean value obtained from all the blood samples drawn to attain the best fitted curve analysis.

\section{RESULTS}

Plasma leucine changes during CECRT. The plasma leucine levels changes during CECRT that were retrospectively 
obtained from the first seven neonates studied resulted in a best fitted curve suggesting a bicompartmental model (Fig. 1). When this model is applied, plasma leucine levels decrease during the first $3 \mathrm{~h}$ according to an exponential curve defined by the equation $[\mathrm{Leu}]_{\mathrm{t}}=[\mathrm{Leu}]_{\mathrm{i}} \times 0.95 \times 10^{-0.09 \mathrm{t}}(r=0.98)$, where $[\mathrm{Leu}]_{\mathrm{t}}$ is the leucine plasma level $(\mu \mathrm{mol} / \mathrm{L})$ at time $\mathrm{t}(\mathrm{h})$ during CECRT and [Leu $]_{\mathrm{i}}$ corresponds to the initial plasma level. From $\mathrm{h} 4$ to the end of CECRT, the change in leucine plasma levels was best described by a second exponential curve defined by the equation $[\mathrm{Leu}]_{\mathrm{t}}=[\mathrm{Leu}]_{\mathrm{i}} \times 0.74 \times 10^{-0.05 \mathrm{t}}$ $(r=0.97)$.

After May 2000, three neonates underwent four CECRT sessions for acute-onset MSUD and their leucine plasma levels were plotted on the previously established leucine kinetic modeling curve (Fig. 2). The actual leucine levels obtained from these patients were compared with the levels predicted by the above equations (Table 3) and were found to be very similar to those predicted by the model. Calculated values derived from the model were slightly higher than the measured level obtained at the 3-h time point of CECRT and the deviation ratio was below $10 \%$ at the end of CECRT.

Patient 9 required two CECRT sessions. His initial plasma leucine level obtained was likely factitiously elevated due to a severe $12 \%$ dehydration that may have contributed to the difference observed between measured and calculated leucine blood levels in Table 3. The first CECRT session was performed after rehydration and interrupted due to filter clotting after $3 \mathrm{~h}$. At the time of cessation, the leucine plasma level was below the established indications for CECRT $(1388 \mu \mathrm{M}$, see Table 2) and specific nutritional support alone was continued. Subsequently, clinical status did not improve, leucine plasma levels rose to $1680 \mu \mathrm{M}$ within $12 \mathrm{~h}$ and a second CECRT session was indicated (Table 2).

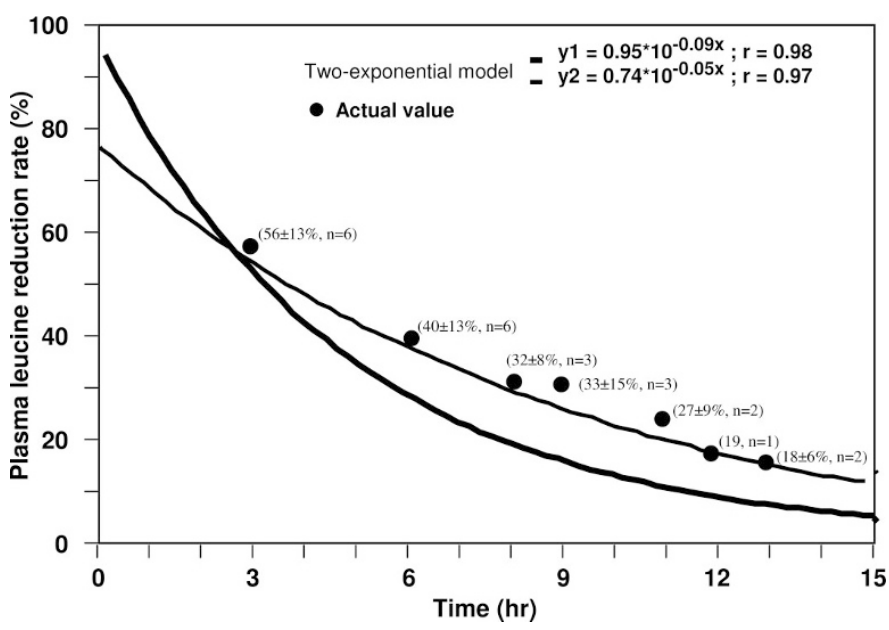

Figure 1. Leucine plasma kinetic modeling obtained from seven neonates with severe acute-onset MSUD treated with CECRT and with specific nutrition. The number of patients, the mean plasma leucine level decrease, and the SD (percentage of initial plasma leucine level) are provided for each value plotted. The leucine reduction rate is correlated with a bicompartmental model. The first 3-h period corresponds to an exponential curve: $[\mathrm{Leu}]_{\mathrm{t}}=[\mathrm{Leu}]_{\mathrm{i}} \times$ $0.95 \times 10^{-0.09 t}(r=0.98)$; and the period from the $\mathrm{h} 4$ to the end of CECRT corresponds to a second exponential curve: $[\mathrm{Leu}]_{\mathrm{t}}=[\mathrm{Leu}]_{\mathrm{i}} \times 0.74 \times 10^{-0.05 \mathrm{t}}$ $(r=0.97)$, where $[\mathrm{Leu}]_{\mathrm{t}}$ is the leucine plasma level $(\mu \mathrm{mol} / \mathrm{L}), \mathrm{t}(\mathrm{h})$ is CECRT duration, and $[\mathrm{Leu}]_{\mathrm{i}}$ is the initial plasma level.

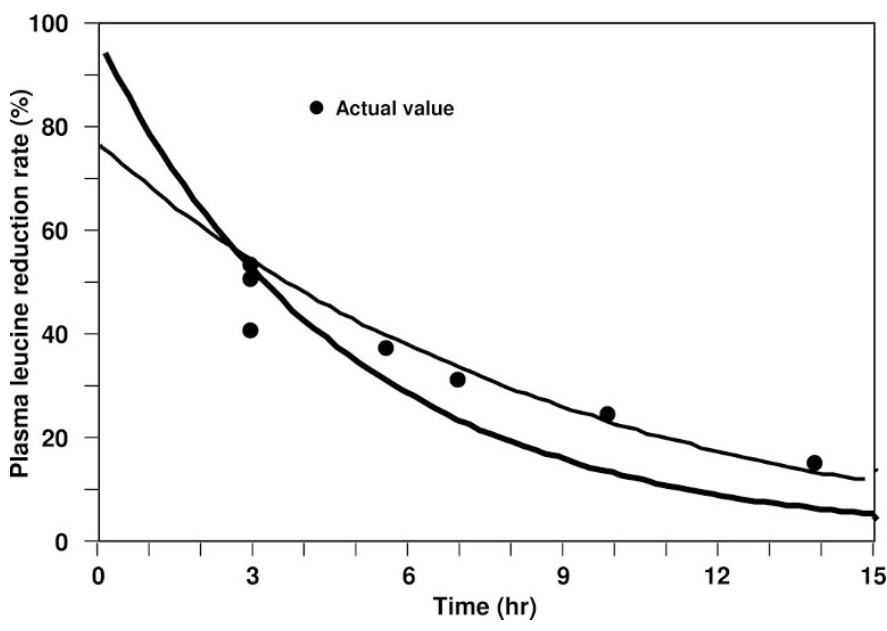

Figure 2. Validation of leucine plasma kinetic modeling. Leucine plasma level decrease in three neonates with MSUD treated by CECRT. Leucine plasma decreases (percentage of plasma leucine level at initiation of CECRT) are plotted on the graph and are close to the bicompartmental model curve.

Leucine distribution volume. The decrease in the plasma leucine concentration was reflected by one exponential equation during the first $3 \mathrm{~h}$ of CECRT and by a different exponential equation for $\mathrm{h} 4$ until CECRT cessation. The volume of distribution measured in the first seven neonates was $34 \pm 3 \%$ of body weight during the first $3 \mathrm{~h}$ and $72 \pm 7 \%$ of body weight for the subsequent time period (Table 1). These values represent the distribution volume of leucine and correspond to the known values for extracellular water space and total body water in the newborn (4).

\section{DISCUSSION}

During CECRT, plasma leucine concentrations in neonates with MSUD decrease according to a bi-exponential profile similar to the handling of nonprotein bound small molecular weight solutes such as urea $(5,6)$. Our study is the first to define the distribution volumes of leucine in neonates and to propose leucine kinetic modeling that provides reliable prediction of the plasma leucine level changes during extracorporeal removal therapy with or without nutrition, thus precluding the need to perform repeated amino acid chromatography analysis.

Several other practical advantages result from reliable kinetic modeling of plasma leucine levels. The most significant impact of this modeling is the fact that it becomes feasible to determine the optimal duration of CECRT based on the leucine plasma level at the time of NICU admission. CECRT duration can easily be calculated with this model to target a plasma leucine level below $1000 \mu \mathrm{M}$, which, in our experience, substantially reduces the risk of neurologic effects (3). For example, it becomes possible to determine that a 7-h CECRT session will be required to decrease the plasma leucine level below $1000 \mu \mathrm{M}$ (a 66\% decrease) in a neonate with an initial leucine plasma concentration of $3000 \mu \mathrm{M}$ when a Miniflow 10 hemofilter is used with a blood flow of $25 \mathrm{~mL} / \mathrm{min}$ and a dialysate flow of $25 \mathrm{~mL} / \mathrm{min}$ without recirculation. If these settings are not used during CECRT, it can still be ascertained that, when the leucine clearance reaches values $>4 \mathrm{~mL} / \mathrm{min}$, the remain- 
Table 3. Comparison between measured $(\mathrm{Cm})$ and calculated $(\mathrm{Cc})$ leucine plasma levels with leucine kinetic modeling during CECRT

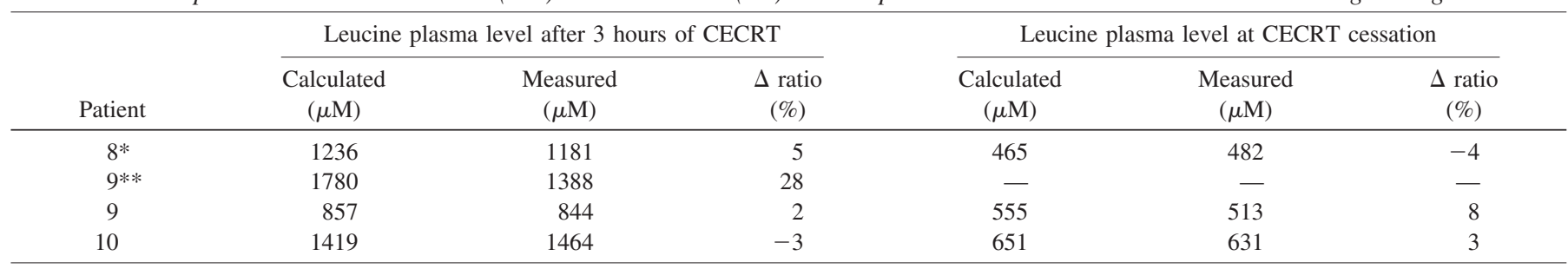

The equations used to calculate leucine levels were: $\mathrm{Cc}=0.95 \times 10^{-0.09 t}$ for the first 3 hours of CECRT and Cc $=0.74 \times 10^{-0.05 t}$ from time 4 hours to cessation of CECRT where $\mathrm{t}(\mathrm{hrs})$ is CECRT duration and $\mathrm{Cc}(\mu \mathrm{M})$ is the calculated leucine blood level at time t. $\Delta$ ratio $(\%)=(\mathrm{Cc}-\mathrm{Cm}) / \mathrm{Cm}$. Patient 9 underwent two CECRT sessions.

CECRT, continuous extra-corporeal removal therapy.

* Level obtained after 5.5 hrs of CECRT.

** Calculated leucine level was obtained using the plasma leucine level at the time of admission when a $12 \%$ of body weight dehydration was present.

ing duration of the session will be $<7 \mathrm{~h}$ regardless of the method (hemofiltration, hemodialysis, or hemodiafiltration) or hemofilter used. In fact, because creatinine and leucine are neutral molecules without protein binding and with a similar molecular weight (113 D and $131 \mathrm{D}$, respectively) and mass transfer coefficient, creatinine clearance may be used in clinical practice to estimate leucine clearance if rapid chromatography analysis is not available (7).

Our data showed that leucine is removed from an average distribution volume of $34 \%$ of body weight during the first $3 \mathrm{~h}$ of CECRT and from a distribution volume of $72 \%$ during the balance of CECRT duration. Butte et al. (4) reported a mean total body water space of $73 \%$ of body weight in the newborn, a value markedly similar to the leucine distribution volume measured for the second CECRT period. The leucine distribution volume estimated by Collins et al. (8) was $46.6 \pm 15.4 \%$ of body weight in 10 healthy adults and similar values were obtained in 3 adults with MSUD. This figure essentially corresponds to the normal fraction of total body water in humans, which is $50-70 \%$ of body weight $(9,10)$. Collins et al. (8) assessed the leucine distribution volume with a $[1-14 \mathrm{C}] \mathrm{L}$ leucine bolus followed by plasma collection over a short period of time $(120 \mathrm{~min})$. When two different compartments are involved, as suggested by our data, the slow leucine diffusion from one compartment to another may result in an underestimation of the distribution volume. This hypothesis of a bicompartmental model with different kinetics in each compartment is supported by our kinetic modeling and by the follow-up of patient 9. Indeed, we observed that the leucine level in this patient increased subsequent to the first 3-h CECRT session. Although this increase could potentially be attributed to either persistent net protein catabolism and/or to transfer of leucine from the intracellular to the extracellular compartment, the latter explanation was deemed more plausible given the fact that the patient was not infected and that nutrition was well tolerated.

In our study, we did not use isotopic methods because the neonates included were not in a steady state condition (11). Instead, we estimated the leucine distribution volume by considering the leucine mass removed and the leucine plasma level decreases that occurred during CECRT. We deemed this estimation to be accurate because both urinary leucine excretion $(<5 \mu \mathrm{mol} / \mathrm{kg} / \mathrm{h})(12)$ and leucine oxidation are negligible in neonates with classical MSUD $(13,14)$. In our study, the main factor that could have affected our estimated distribution volume is protein metabolism, because proteolysis can liberate leucine from the protein pool and protein synthesis can result in the incorporation of leucine into the protein pool (Fig. 3). Protein metabolism had a negligible effect on our estimation of leucine distribution volume for the following reasons. First, changes in plasma leucine levels occur slowly with wholebody leucine turnover and at a rate much slower than that seen during CECRT. Indeed, maximal plasma leucine variations in neonates are reported to be increases in the order of $30 \mu \mathrm{M} / \mathrm{h}$ with predominant proteolysis (15) and decreases in the order of $20 \mu \mathrm{M} / \mathrm{h}$ with protein synthesis (16), changes that are markedly smaller than the $180 \mu \mathrm{M} / \mathrm{h}$ decreases seen with CECRT (see Table 1). Second, during CECRT, leucine turnover from proteolysis to protein synthesis results in only a slight effect on leucine plasma levels. The seven neonates included in our study were not infected, which suggests that the increased leucine plasma levels present at admission were attributable mainly to the BCAA contained in the dietary intake before admission and to a fasting state with protein catabolism secondary to neurologic impairment. Therefore, dietary intake free of BCAA associated with initiation of CECRT results in a switch from net proteolysis to net protein synthesis. This hypothesis was supported by the fact that leucine plasma levels were increasing in all seven neonates before treatment and by the fact that the decrease in leucine plasma levels was ongoing even after cessation of CECRT (data not shown).

Assessment of the distribution volume can be very helpful in clinical practice. In moderate MSUD with an acute onset, leucine is mainly removed by prompt enteral administration of a BCAA-free formula (17), a specific nutritional regimen

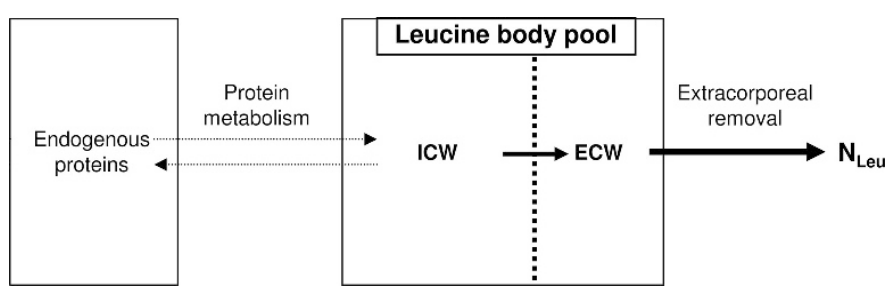

Figure 3. Schema of the bicompartmental model of leucine fluxes in MSUD. $I C W$, intracellular water space; $E C W$, extracellular water space; $N_{\text {Leu }}$, leucine mass removed by continuous extracorporeal removal therapy. 
aimed at achieving maximal leucine incorporation into protein synthesis. In such circumstances, leucine plasma level decreases may be estimated by using urinary urea excretion, initial plasma leucine levels, and patient body weight. Using the distribution volume, free body leucine mass $\left(\mathrm{N}_{\text {body }}\right)$ is calculated from the following equation: $\mathrm{N}_{\text {body }}=[\mathrm{Leu}] \times 0.72$ $\times$ body weight. Using urea urinary excretion, net protein anabolism is estimated (3). Given that leucine represents $10 \%$ of mammalian proteins, leucine mass incorporated into protein synthesis can be estimated according to the following equation: Leucine mass removal by specific nutritional regimen $(\mathrm{mmol})$ $=$ net protein anabolism $(\mathrm{mg} / 24 \mathrm{~h}) * 0.1 / 131$ (leucine molecular weight). Given that both leucine mass removal by protein anabolism and total leucine body mass can be estimated, the delay required to obtain a specific leucine level can be estimated.

Our data may also be helpful in the management of older children and adults, particularly with regard to the indication for CECRT. In these patients, total water space is proportionately smaller $(50-60 \%)$ and body weight is increased, thus implying there is a greater leucine pool to remove. Moreover, leucine incorporation into protein synthesis does not increase in a manner proportional to body weight in these older children and adults (13). When severe leucine intoxication occurs in these patients, it becomes essential to establish how much more slowly the leucine pool decreases when protein synthesis becomes active. Our kinetic modeling may also help to evaluate CECRT duration by utilizing a standardization of the leucine clearance to body surface. Given that a newborn has an approximate $0.2 \mathrm{~m}^{2}$ body surface area, it can be expected that leucine plasma levels in older children will decrease at a rate similar to that shown in Figure 1 if a leucine clearance of at least $35 \mathrm{~mL} / \mathrm{min} \cdot 1.73 \mathrm{~m}^{2}(4 \mathrm{~mL} / \mathrm{min} \times 1.73 / 0.2)$ is done. In a 10-y-old child with acute-onset MSUD, Hmiel et al. (7) reported a leucine clearance of $22.7 \mathrm{~mL} / \mathrm{min} \cdot 1.73 \mathrm{~m}^{2}$ with plasma levels dropping from an initial value of $2585 \mu \mathrm{M}$ to a level below $1000 \mu \mathrm{M}$ after $24 \mathrm{~h}$ of CECRT (61\% decrease). According to our kinetic modeling and with a leucine clearance of $35 \mathrm{~mL} / \mathrm{min} \cdot 1.73 \mathrm{~m}^{2}, 6-8 \mathrm{~h}$ would probably have been sufficient to attain a $60 \%$ decrease. Further studies are needed to confirm this hypothesis.

Given that it is now possible to estimate the effect of nutrition and CECRT efficiency on leucine removal in MSUD, several questions remain to be debated: How fast should we remove leucine if CECRT is performed in neonates? This question is of great interest given that a recent study suggests that specific nutrition alone can be a favorable option with early diagnosis (in infants aged less than $7 \mathrm{~d}$ ) regardless of the initial leucine plasma level (17). The second question to be debated deals with the concept of a bicompartmental system, especially in the brain. A high leucine clearance (18) may mainly remove molecules from the extracellular water space and expose newborns to a sudden osmolarity shift, which could be deleterious in the context of cerebral edema. Further studies are necessary to fully evaluate the balance between the risks associated with CECRT and the risk of neurologic sequelae due to prolonged exposure to high leucine levels.

\section{REFERENCES}

1. Saudubray J, Ogier H, Charpentier C, Depondt E, Coude F, Munnich A, Mitchell G, Rey F, Rey J, Frézal J 1984 Neonatal management of organic acidurias. Clinical update. J Inher Metab Dis 7:2-9

2. Thompson GN, Butt WW, Shann FA, Kirby DM, Henning RD, Howells DW, Osborne A 1991 Continuous venovenous hemofiltration in the management of acute decompensation in inborn errors of metabolism. J Pediatr 118:879-884

3. Jouvet P, Jugie M, Rabier D, Desgres J, Hubert P, Saudubray JM, Man NK 2001 Combined nutritional support and continuous extracorporeal removal therapy in the severe acute phase of maple syrup urine disease. Intensive Care Med 27:1798-1806

4. Butte NF, Hopkinson JM, Wong WW, Smith EO, Ellis KJ 2000 Body composition during the first 2 years of life: an updated reference. Pediatr Res 47:578-585

5. Sharma A, Espinosa P, Bell L, Tom A, Rodd C 2000 Multicompartment urea kinetics in well-dialyzed children. Kidney Int 58:2138-2146

6. Vanholder R, Burgelman M, De Smet R, Voogeleere P, Ringoir S 1996 Two-pool versus single-pool models in the determination of urea kinetic parameters. Blood Purif 14:437-450

7. Hmiel S, Martin RA, Landt M, Levy FH, Grange DK 2004 Amino acid clearance during acute metabolic decompensation in maple syrup urine disease treated with continuous venovenous hemodialysis with filtration. Pediatr Crit Care Med 5:278281

8. Collins JE, Umpleby AM, Boroujerdi MA, Leonard JV, Sonksen PH 1987 Effect of insulin on leucine kinetics in maple syrup urine disease. Pediatr Res 21:10-13

9. Smith D, Engel B, Diskin AM, Spanel P, Davies SJ 2002 Comparative measurements of total body water in healthy volunteers by online breath deuterium measurement and other near-subject methods. Am J Clin Nutr 76:1295-1301

10. Ellis KJ, Wong WW 1998 Human hydrometry: comparison of multifrequency bioelectrical impedance with $2 \mathrm{H} 2 \mathrm{O}$ and bromine dilution. J Appl Physiol 85:10561062

11. Bodamer OA, Halliday D 2001 Uses of stable isotopes in clinical diagnosis and research in the paediatric population. Arch Dis Child 84:444-448

12. Schadewaldt P, Hammen HW, Ott AC, Wendel U 1999 Renal clearance of branchedchain L-amino and 2-oxo acids in maple syrup urine disease. J Inher Metab Dis 22:706-722

13. Schadewaldt P, Bodner-Leidecker A, Hammen HW, Wendel U 2001 Whole-body L-leucine oxidation in patients with variant form of maple syrup urine disease. Pediatr Res 49:627-635

14. Thompson GN, Bresson JL, Pacy PJ, Bonnefont JP, Walter JH, Leonard JV, Saudubray JM, Halliday D 1990 Protein and leucine metabolism in maple syrup urine disease. Am J Physiol 258:E654-E660

15. Schadewaldt P, Wendel U 1997 Metabolism of branched-chain amino acids in maple syrup urine disease. Eur J Pediatr 156:S62-S66

16. Parini R, Sereni LP, Bagozzi DC, Corbetta C, Rabier R, Narcy C, Hubert P, Saudubray JM 1993 Nasogastric drip feeding as the only treatment of neonatal maple syrup urine disease. Pediatrics 92:280-283

17. Morton DH, Strauss KA, Robinson DL, Puffenberger EG, Kelley RI 2002 Diagnosis and treatment of maple syrup disease: a study of 36 patients. Pediatrics 109:999-1008

18. Schaefer F, Straube E, Oh J, Mehls O, Mayatepek E 1999 Dialysis in neonates with inborn errors metabolism. Nephrol Dial Transplant 14:910-918 